\title{
Long-term parasitic association between the boring polychaete Polydora bioccipitalis and Mesodesma donacium
}

\author{
José M. Riascos ${ }^{1,2, *}$, Nury Guzmán ${ }^{3}$, Jürgen Laudien², Marcelo E. Oliva ${ }^{1}$, \\ Olaf Heilmayer ${ }^{2,4}$, Luc Ortlieb ${ }^{3}$
}

${ }^{1}$ Universidad de Antofagasta, Instituto de Investigaciones Oceanológicas, Avenida Angamos 601, Antofagasta, Chile

${ }^{2}$ Alfred Wegener Institute for Polar and Marine Research, Am Alten Hafen 26, 27568 Bremerhaven, Germany

${ }^{3}$ Institut de Recherche pour le Développement (IRD), PALEOTROPIQUE (Paléoenvironnements tropicaux et variabilité climatique), 32 Avenue Henri Varagnat, 93143 Bondy Cedex, France

${ }^{4}$ International Bureau of the Federal Ministry of Education and Research c/o German Aerospace Center (DLR), Heinrich-Konen-Str. 1, 53227 Bonn, Germany

\begin{abstract}
Polydora and related genera are common pests for molluscs. Establishing differences between native species and recent invaders provides the basis for understanding the effect of parasites and has implications for resource management. $P$. biocipitalis has been reported as a recently introduced species to the Chilean-Peruvian coast, raising concerns about its threat to native bivalve species. In contrast, studies on the infestation of $P$. bioccipitalis on the surf clam Mesodesma donacium, one of the most important species for shellfisheries, suggest a long-term parasitic relationship. The present study analyses infested (i.e. blistered) fossil shells of $M$. donacium deposited during the Holocene and Middle Pleistocene epochs and critically reviews evidence supporting the hypothesis of the recent introduction of $P$. bioccipitalis to the Chilean-Peruvian coast. The blistering pattern seen on fossil and recent shells can be considered species-specific for the infestation of M. donacium by $P$. bioccipitalis. No evidence was actually found on vectors, introduction pathways or distribution range to support the status of $P$. bioccipitalis as an introduced species. On the contrary, our findings point to a long-term association, at least for several hundred thousand years, between M. donacium and P. bioccipitalis.
\end{abstract}

KEY WORDS: Blister worm · Trace fossil polychaetes $\cdot$ Non-indigenous species $\cdot$ Mollusc parasites Resale or republication not permitted without written consent of the publisher

\section{INTRODUCTION}

Spionid worms of the genus Polydora and related genera, commonly termed polydorids, are the most common parasitic boring polychaetes and are distributed worldwide (Lauckner 1983, Martin \& Britayev 1998, Ruellet 2004). First described in the late 1800s, their ability to bore into calcareous substrates has labelled polydorids as pests on cultured and wild commercially important molluscs (Handley 1995, Lleonart et al. 2003, Simon et al. 2006). International shipping activities and aquaculture are well-recognized means that disperse species beyond their native regions (Naylor et al. 2001, Castilla et al. 2005). The current development of aquaculture in Chile focuses on several introduced species (e.g. salmon, abalone, oyster) which harbour pathogens that can affect the native fauna (Buschmann et al. 1996). There is evidence of the accidental introduction of polydorid worms as a result of importing abalone brood stocks (Radashevsky \& Olivares 2005). Recently a study showed that 6 polydorid species are non-indigenous species (NIS, sensu Carlton 1996) invading Chilean waters (Moreno et al. 2006). The accelerating invasion of marine systems by 
NIS has become a subject of environmental concern, because they act as stressors, which affect native species, community structure and function as well as ecosystems (D'Antonio \& Vitousek 1992, Orensanz et al. 2002).

While it is clear that human activities are continuously enhancing the natural dispersal processes of some species (e.g. McKinney \& Lockwood 1999), establishing a time frame of parasitic relationships of potentially invasive species is a crucial step for understanding their long-term natural ability to expand their populations. Unfortunately, the reporting of parasitism in the fossil record, particularly invertebrate parasites, is scarce (Huntley 2007) and this lack of knowledge gives rise to misinterpretations about the introduced or native origins of parasites.

In this study, we report the case of Polydora bioccipitalis (Blake \& Woodwick 1971), which has been included in the group of polydorid NIS invading Chilean waters, thus raising concerns about the threat for native and commercial mollusc species (Moreno et al. 2006). The surf clam Mesodesma donacium (Lamarck 1818), one of the most important species for artisanal fisheries of Chile and Peru (McLachlan et al. 1996, Thiel et al. 2007), is commonly infested with $P$. bioccipitalis (Blake 1983). Recent studies have implied that a parasitic association exists with a certain degree of coadaptation, which is inconsistent with the classification of the polydorid as a NIS. First, experimental data showed that the strong infestation significantly affected the growth rate, body condition and digging time of the host (Riascos et al. 2008). In addition, a size-related pattern of mortality in the field revealed that heavily infested clams are more likely to die under environmental stress (Riascos 2009). On the other hand, the reproductive strategy of $P$. bioccipitalis seems to be closely related to the life history traits of M. donacium (Olivares 2006).

As invasive species pose specific and resource-consuming management needs, resolving whether the polydorids are of an introduced or native origin is important in the context of rising global demand for healthy seafood. To this end, the present study aims to (1) report trace fossils in Mesodesma donacium shells in several fossiliferous deposits from Chile, (2) comparatively analyse the blistering pattern of fossil and recent shells of $M$. donacium as evidence for the long-term existence of the Polydora bioccipitalisM. donacium association, and (3) review the evidence that will define the status of $P$. bioccipitalis as a native or NIS.

\section{MATERIALS AND METHODS}

Fossil shell valves of Mesodesma donacium $(\mathrm{N}=183)$ were collected at 3 fossiliferous coastal deposits north of Antofagasta (Michilla, 22 $2^{\circ} 43^{\prime} \mathrm{S}, 70^{\circ} 16^{\prime} \mathrm{W}$; Chacaya, $22^{\circ} 57^{\prime} \mathrm{S}, 70^{\circ} 18^{\prime} \mathrm{W}$; Las Lozas, $23^{\circ} 28^{\prime} \mathrm{S}, 70^{\circ} 28^{\prime} \mathrm{W}$ ), and at Los Porotitos $\left(29^{\circ} 48^{\prime} \mathrm{S}, 71^{\circ} 17^{\prime} \mathrm{W}\right)$ near La Serena (Fig. 1). These deposits correspond to well-preserved sequences of sediments associated with marine terraces formed during high sea stands of the last interglacial periods (marine isotopic stages). The age of each fossiliferous deposit was determined by using a combination of geochronological and geomorphological approaches (Radtke 1989, Leonard \& Wehmiller 1991, 1992, Ortlieb et al. 1995, 1996, see Table 1).

For comparison purposes, recent Mesodesma donacium shells ( $\mathrm{N}=665)$ collected at Hornitos $\left(22^{\circ} 54.99^{\prime} \mathrm{S}\right.$, $70^{\circ} 17.42^{\prime}$ W, Fig. 1) between May 2005 and April 2006 were analysed. For both fossil and recent shells, the anterior-posterior shell length (SL) was measured to the nearest $0.5 \mathrm{~mm}$ and the presence and location of blisters were recorded. Blisters were exposed by fracturing the walls with a scalpel and hammer to uncover internal features. Fossil and recent shells analysed are deposited at the Institut de Recherche pour le Dévelopment (IRD)-Universidad de Antofagasta Paleontological Collection (Antofagasta, Chile) and selected specimens were deposited at the Museo Nacional de Historia Natural de Chile. A variance ratio test (Zar 1999) was used to test for differences between SL variance of blistered fossil and recent shells. The Shapiro-

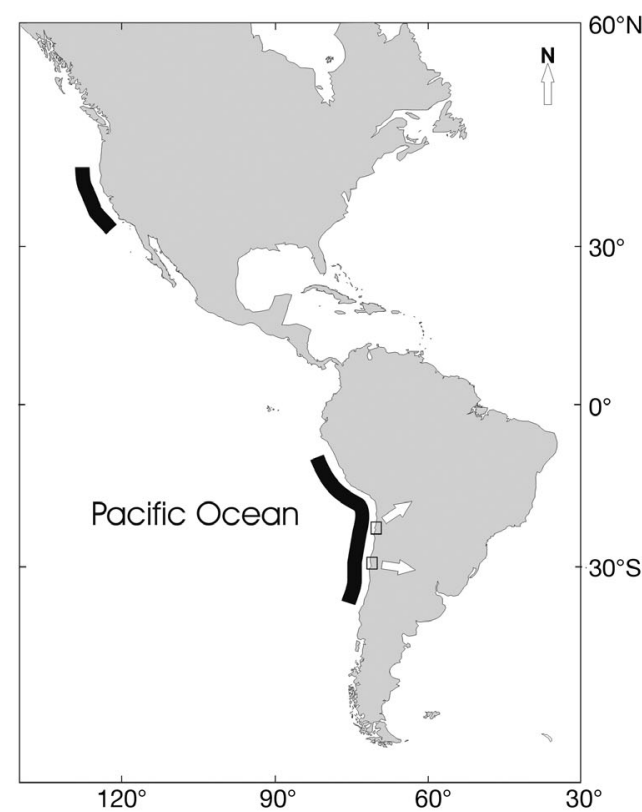

Fig. 1. Geographic distribution of Polydora bioccipitalis (black line) and collection places of fossil (†) and recent (•) Mesodesma donacium
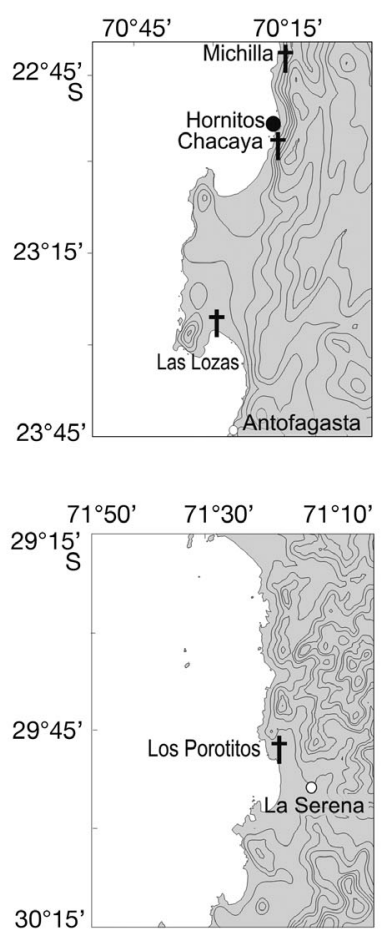
Wilks test was used to assess normality of each data set, as needed to meet the assumptions of this test.

\section{RESULTS}

Ages of fossil Mesodesma donacium shells from coastal deposits varied from the Holocene (6725 to $6990 \mathrm{yr}$ BP) at Michilla to the Middle Pleistocene (120000 to $330000 \mathrm{yr}$ BP) at Chacaya, Las Lozas and Los Porotitos (Table 1). The polydorid infestation of $M$. donacium was apparent exclusively in the formation of mud blisters (sensu Blake \& Evans 1973) in the inner shell surface, with no signs of burrowing on the exterior shell surface, as is commonly observed for most polydorid infestations. The blistering pattern of both fossil and recent shells was identical and specific: blisters were about the same size ( 8 to $23 \mathrm{~mm}$ wide and 13 to $48 \mathrm{~mm}$ long) and were exclusively located near the posterior shell margin, surrounding the posterior adductor muscle insertion and the paleal sinus (Fig. 2a,b). Moreover, blisters were formed in a progressively large series (Fig. 2c) of up to 8 blisters in larger clams. Earlier (smaller) blisters were consistently located near the dorsal margin, while blisters that formed later (larger) were located near the ventral margin (Fig. 2c). Blisters are generally pear-shaped, with the narrow end communicating with the outside at the posterior shell margin.

Blisters of recent shells were filled with detrital material deposited by the polychaete, which builds a U-shaped detrital tube inside the blister. Tube openings communicate with the outside of the shell (Fig. 2c) allowing the worm to feed near the inhalant current of the clam. The continuous back and forth movement of the worm along the detrital tubes commonly produces a scar in the internal blister wall, revealing the position of the U-shaped detrital tubes inside the blister. No traces of internal detrital tubes were recorded in fossil blisters, but U-shaped scars were evident and comparable with those of recent shells (Fig. 2a,b), which allowed estimates of worm lengths ( 32 to $38 \mathrm{~mm})$ and diameters ( $\sim 0.8$ to $1.0 \mathrm{~mm}$ ) to be calculated. These estimates corresponded with measurements of living Polydora bioccipitalis (Fig. 2b).

Overall, the infestation (i.e. recordable blisters) of fossil and recent shells was restricted to larger shells (SL > $32 \mathrm{~mm}$ ) as shown by the size-blister distribution (Fig. 3). Blistered fossil shells ranged between 43.7 and $105.6 \mathrm{~mm}$, whereas recent infested shells ranged from 34.0 to $96.0 \mathrm{~mm}$. The variance ratio test showed no differences in SL variance between blistered fossil and recent shells $\left(F_{25,192}=1.69, \mathrm{p}<0.05\right)$.

\section{DISCUSSION}

In a review on boring spionid polychaetes, Moreno et al. (2006) reported 6 species (including Polydora bioccipitalis) that could be classified as NIS, based on criteria outlined by Orensanz et al. (2002) and Castilla et al. (2005). For P. bioccipitalais, no direct evidence on vectors and introduction pathways to the ChileanPeruvian coast was found. Moreno et al. (2006) based their classification as NIS on the apparently notorious, biogeographically incongruous distribution range, its recent record outside the 'native or historic' distribution range, i.e. California (USA) and the North Atlantic (Europe: France, UK, Ireland, North Sea) and its 'introduced range' as the South Pacific (Chile, Australia, New Zealand). However, an analysis of the references provided by Moreno et al. (2006, Table 2 therein) and extensive literature research revealed a different distribution range of $P$. bioccipitalis, which is restricted to the eastern coast of North and South America (Fig. 1).

Polydora bioccipitalis was first described by Blake \& Woodwick (1971) from Malibu Beach $\left(34^{\circ} 02^{\prime} \mathrm{N}\right.$, $118^{\circ} 48^{\prime} \mathrm{W}$ ) and Santa Barbara (34 $\left.24^{\prime} \mathrm{N}, 119^{\circ} 40^{\prime} \mathrm{W}\right)$, California, as a commensal of the hermit crabs Pagurus hirsutiusculus that inhabited gastropod shells (Murex gemma, Ocenebra poulsoni, Polinices reclusianus and Olivella biplicata). Since then, all additional records of $P$. bioccipitalis refer to the Chilean-Peruvian coast. Rozbaczylo et al. 1980) reported P. bioccipitalis inhab-

Table 1. Locality and geochronological methods used to assign ages to each fossiliferous deposit

\begin{tabular}{|c|c|c|c|}
\hline Locality & Geochronological method & Age & Source \\
\hline \multirow[t]{2}{*}{ Michilla } & ${ }^{14} \mathrm{C}$ dating & $6725 \pm 95$ yr BP & Leonard \& Wehmiller (1991) \\
\hline & Th/U dating & $6990 \pm 80$ yr BP & Ortlieb et al. (1995) \\
\hline \multirow[t]{2}{*}{ Chacaya } & Aminostratigraphy & Marine Isotopic Stage 5 & Radtke (1989) \\
\hline & Th/U dating and morphostratigraphy & $\sim 120000$ yr BP & Ortlieb et al. (1996) \\
\hline \multirow[t]{2}{*}{ Las Lozas } & Th/U dating and electron spin resonance & Marine Isotopic Stage 9 & Radtke (1989) \\
\hline & Aminostratigraphy and morphostratigraphy & $\sim 330000$ yr BP & Ortlieb et al. (1996) \\
\hline \multirow[t]{2}{*}{ Los Porotitos } & Th/U dating and electron spin resonance & Marine Isotopic Stage 9 & Radtke (1989) \\
\hline & Aminostratigraphy & $\sim 330000$ yr BP & Leonard \& Wehmiller (1992) \\
\hline
\end{tabular}



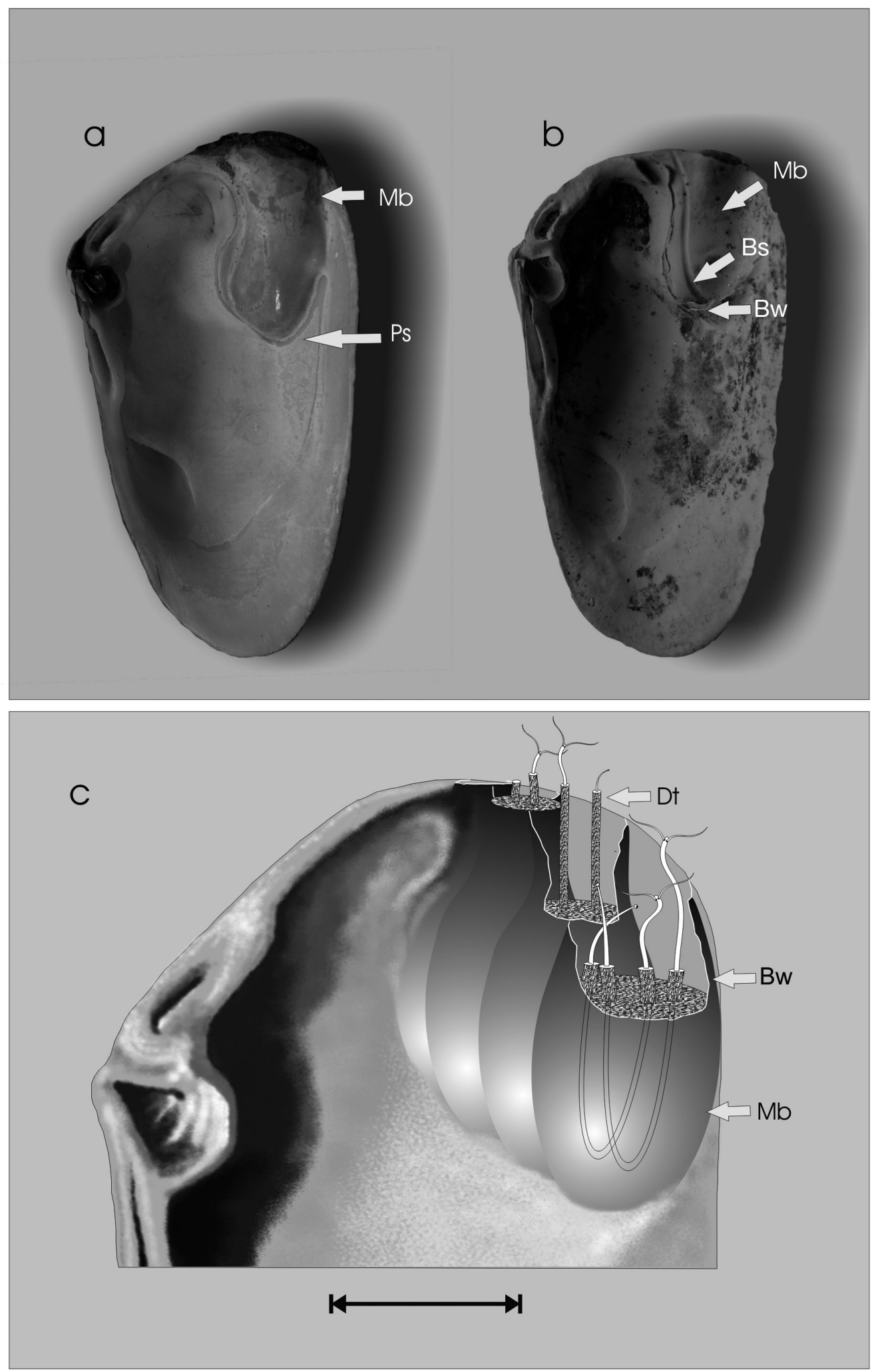

Fig. 2. Mesodesma donacium. Blistering pattern of (a) recent shell collected from Hornitos, northern Chile, and (b) fossil valve from Middle Pleistocene deposits of Los Porotitos, central Chile; (c) line drawing of the internal features of the blistering produced by the infestation of Polydora bioccipitalis in shells. Mb: mud blister; Ps: paleal sinus; Bs: blister scar; Bw: blister wall; Dt: detrital tube. Scale bar $=2 \mathrm{~cm}$ 


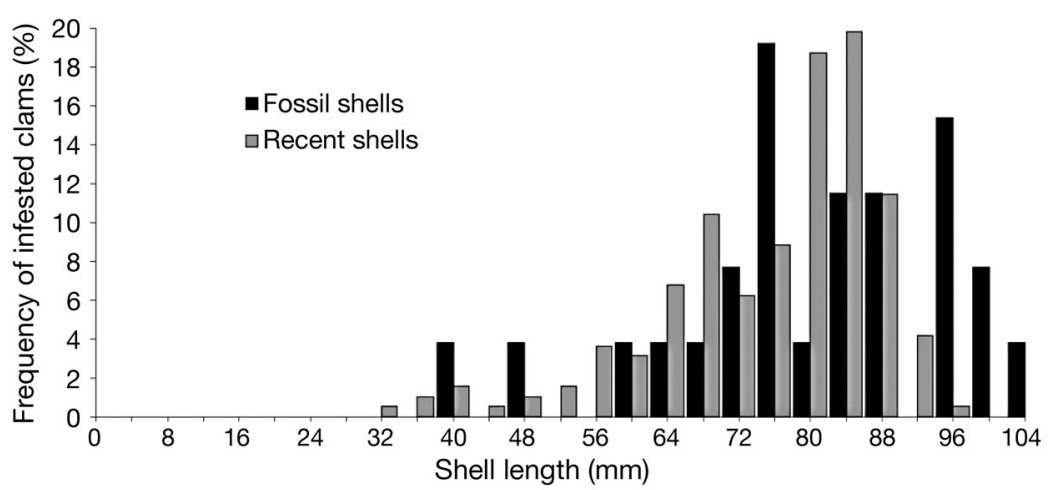

Fig. 3. Mesodesma donacium. Frequency distribution of maximum anteriorposterior shell lengths of blistered fossil and recent shells

iting shells of living Mesodesma donacium from Playa Morrillos $\left(30^{\circ} 09^{\prime} \mathrm{S}, 71^{\circ} 22^{\prime} \mathrm{W}\right)$, and Blake (1983) reported it from mud blisters of $M$. donacium from Playa Aguila $\left(20^{\circ} 54^{\prime} \mathrm{S}, 70^{\circ} 08^{\prime} \mathrm{W}\right), 100 \mathrm{~km}$ south of Iquique. Additionally, Moreno et al. (2006) recorded P. bioccipitalis from a specimen of the clam Mulinia edulis, col-

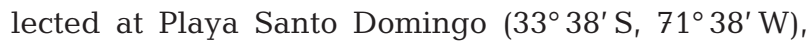
south of the port of San Antonio. Finally, Riascos et al. (2008) showed a latitudinal gradient of increasing prevalence of $P$. bioccipitalis infesting $M$. donacium from southern Chile $\left(42^{\circ} \mathrm{S}, 74^{\circ} \mathrm{W}\right)$ to central Peru $\left(12^{\circ} \mathrm{S}, 77^{\circ} \mathrm{W}\right)$. It is worth noting that $P$. bioccipitalis does not infest Crepidula fecunda, Crepidula sp. and Fissurella nigra as inferred by Moreno et al. (2006, Table 1 therein) from the studies of Sato-Okoshi \& Takatsuka (2001) and Bertrán et al. (2005). According to these authors, the gastropods mentioned are only infested by $P$. rickettsi, Dipolidora huelma and $D$. giardii.

Although discontinuous (Fig. 1), the observed geographic distribution range of Polydora bioccipitalis cannot be considered incongruous. At least 3 spionid species ( $P$. cirrosa, P. rickettsi, and Boccardia tricuspa) present a similar distribution pattern in western South and North America (Blake 1983, Ruellet 2004). This may reflect the fact that while the northern $(42$ species from California) and southern (19 species from South America) spionid fauna has been relatively well sampled and described, the coastal tropical regions of Latin America have been neglected (2 to 6 species) (Ruellet 2004, Fig. 38 therein). Interestingly, Kern et al. (1974) reported fossil spionid tubes in gastropod shells occupied by hermit crabs found in the Pliocene and Pleistocene strata of California and Baja California similar to those constructed by $P$. commensalis and $P$. bioccipitalis. This, and the trace fossils described here from Middle Pleistocene deposits, suggest that $P$. bioccipitalis has been present at both ends of the distributional range for a long time.
Studies on the relationship between the boring activity of polydorid species and their habitat have demonstrated that burrowing patterns are species-specific (Sato-Okoshi \& Okoshi 1997, SatoOkoshi \& Takatsuka 2001). Three main types of polydorid burrows in bivalve shells have been well described by Blake \& Evans (1973): (1) surface fouling, which occurs when the worm settles on a surface and builds a detrital burrow, but does not penetrate; (2) U-shaped burrows that penetrate the structure of the shell, the basic pattern typical of Polydora shell infestations; and (3) mud blisters, which result when the worm reaches the inner surface of the shell, either by crawling between the mantle and the inner shell surface or by shell penetration, and the host secretes new shell layers to isolate the worm. Concurrently, the worms fill the newly formed space with loose mud and then compress it, leaving U-shaped detrital tubes that communicate with the exterior. Although surface fouling by $P$. bioccipitalis has been observed during early infestation stages on juvenile Mesodesma donacium (Riascos et al. 2008), direct shell excavation by the polychaete was never observed. Evidence of the infestation in fossil and recent shells consisted exclusively of a rather specific and serial blistering pattern (Fig. 2).

Single mud blisters have been frequently reported in bivalve shells infested by polydorids (see revisions by Blake \& Evans 1973, Lauckner 1983, Martin \& Britayev 1998 and references therein). However, the shell blistering pattern observed in Mesodesma donacium infested by Polydora bioccipitalis presents distinctive structural features not previously reported and, therefore, can be considered species-specific. First, a series of blisters is formed in response to an infestation. Second, blisters are consistent in form and location, allowing one or more worms to nourish in the feeding current generated by the clam. Third, although worms of the genus Polydora are known for their ability to bore (Blake 1969, 1980, Blake \& Evans 1973), blisters of $M$. donacium shells are formed without evidence of boring activity. In addition, no differences were found in the SL range between blistered (i.e. infested) fossil and recent shells (Fig. 3). The shell size range, in which the infestation takes place, is a distinctive feature of the association between the 2 species, as the infestation of juvenile $M$. donacium depends on ontogenetic changes in shell morphology that increase the susceptibility to infestation (Riascos et al. 2008). It is often difficult to assign taxonomic identity to species producing trace fossils, as evidence of life activities rather than soft tissues are being considered (Cameron 1969). 
However, the singularity of the described shell blistering, the similarity of the blister characteristics in fossil and recent shells and the fact that $P$. bioccipitalis is the only known polychaete associated with $M$. donacium (Blake 1983, Moreno et al. 2006, Riascos et al. 2008) strongly suggest that blisters in fossil shells were produced due to $P$. bioccipitalis infestations.

In conclusion, our findings strongly imply a longterm association, at least since the Middle Pleistocene (120 000 to 330000 yr BP), between Mesodesma donacium and Polydora bioccipitalis and indicate that this spionid worm was not introduced by human activity to the Chilean-Peruvian coast.

Acknowledgements. The authors thank M. Cuturrufo and A. Siffedine for providing logistical support. This study was financed and conducted in the frame of the EU-INCO project CENSOR (Climate variability and El Niño Southern Oscillation: Implications for Natural Resources and Management, contract 511071) and is CENSOR publication 0357. The Programa Bicentenario de Ciencia y Tecnología de Chile, CENSOR-RUE 02 granted a scholarship to J.M.R. to complete this research. The fossil material used here was collected in the framework of a collaborative program between the Institut de Recherche pour le Développement and the Facultad de Ciencias del Mar, Universidad de Antofagasta.

\section{LITERATURE CITED}

Bertrán C, Vargas L, Quijón P (2005) Infestation of Polydora rickettsi (Polychaeta: Spionidae) in shells of Crepidula fecunda (Mollusca: Calyptraeidae) in relation to intertidal exposure at Yaldad Bay, Chiloé, Chile. Sci Mar 69:99-103

Blake JA (1969) Systematics and ecology of shell-boring polychaetes from New England. Am Zool 9:813-820

Blake JA (1980) Polydora and Boccardia species (Polychaeta: Spionidae) from western Mexico, chiefly from calcareous habitats. Proc Biol Soc Wash 93:947-962

Blake JA (1983) Polychaetes of the family Spionidae from South America, Antarctica and adjacent seas and islands. Biology of the Antarctic Seas XIV. Antarct Res Ser 39:205-288

Blake JA, Evans JW (1973) Polydora and related genera as borers in molluscs shells and other calcareous substrates. Veliger 15:235-249

Blake JA, Woodwick KH (1971) New species of Polydora (Polychaeta: Spionidae) from the coast of California. Bull South Calif Acad Sci 70:72-79

Buschmann AH, López DA, Medina A (1996) A review of the environmental effects and alternative strategies of marine aquaculture in Chile. Aquac Eng 15:397-421

Cameron B (1969) Paleozoic shell-boring annelids and their trace fossils. Am Zool 9:689-703

Carlton J (1996) Biological invasions and cryptogenic species. Ecology 77:1653-1655

Castilla JC, Uribe M, Bahamonde N, Clarke M and others (2005) Down under the southeastern Pacific: marine nonindigenous species in Chile. Biol Invasions 7:213-232

D'Antonio CM, Vitousek PM (1992) Biological invasions by exotic grasses, the grass-fire cycle, and global change. Annu Rev Ecol Syst 23:63-87

Handley SJ (1995) Spionid polychaetes in Pacific oysters,
Crassostrea gigas (Thunberg) from Admiralty Bay, Marlborough Sounds, New Zealand. NZ J Mar Freshw Res 29:305-309

> Huntley JW (2007) Towards establishing a modern baseline for paleopathology: trace-producing parasites in a bivalve host. J Shellfish Res 26:253-259

Kern JP, Grimmer JC, Lister KH (1974) A new fossil spionid tube, Pliocene and Pleistocene of California and Baja California. J Paleontol 48:978-982

Lauckner G (1983) Diseases of mollusca: Bivalvia. In: Kinne O (ed) Diseases of marine animals, Vol II. Biologische Anstalt Helgoland, Hamburg, p 477-879

Leonard E, Wehmiller JF (1991) Geochronology of marine terraces at Caleta Michilla, northern Chile: implications for late Pleistocene and Holocene uplift. Rev Geol Chile 18: 81-86

Leonard E, Wehmiller JF (1992) Low uplift rates and terrace reoccupation inferred from mollusk aminostratigraphy, Coquimbo Bay area, Chile. Quat Res 38:246-259

> Lleonart M, Handlinger J, Powell M (2003) Spionid mudworm infestation of farmed abalone (Haliotis spp.). Aquaculture 221:85-96

Martin D, Britayev TA (1998) Symbiotic polychaetes: review of known species. Oceanogr Mar Biol Annu Rev 36: $217-340$

McKinney ML, Lockwood JL (1999) Biotic homogenization: a few winners replacing many losers in the next mass extinction. Trends Ecol Evol 14:450-453

McLachlan A, Dugan J, Defeo O, Ansell AD, Hubbard DM, Jaramillo E, Penchaszadeh PE (1996) Beach clam fisheries. Oceanogr Mar Biol Annu Rev 34:163-232

Moreno RA, Neill PE, Rozbaczylo N (2006) Native and nonindigenous boring polychaetes in Chile: a threat to native and commercial mollusc species. Rev Chil Hist Nat 79: 263-278

> Naylor RL, Williams SL, Strong DR (2001) Aquaculture-a gateway for exotic species. Science 294:1655-1656

Olivares C (2006) Asociación de Polydora bioccipitalis (Polychaeta: Spionidae) y Mesodesma donacium (Bivalvia: Mesodesmatidae) en Bahía Tongoy: su caracterización y dinámica poblacional del huésped. BSc thesis, Universidad Católica del Norte, Coquimbo

Orensanz JM, Schwindt E, Pastorino G, Bortolus A and others (2002) No longer a pristine confine of the world ocean - a survey of exotic marine species in the southwestern Atlantic. Biol Invasions 4:115-143

Ortlieb L, Goy JL, Zazo C, Hillaire-Marcel C, Vargas G (1995) Late Quaternary coastal changes in northern Chile. Guidebook for a field trip. II. Annual Meeting of the International Geological Correlation Program, Project 367 (Antofagasta, 19-28 Nov, 1995). ORSTOM, Antofagasta

Ortlieb L, Diaz A, Guzmán N (1996) A warm interglacial episode during oxygen isotope stage 11 in northern Chile. Quat Sci Rev 15:857-871

> Radashevsky VI, Olivares C (2005) Polydora uncinata (Polychaeta: Spionidae) in Chile: an accidental transportation across the Pacific. Biol Invasions 7:489-496

Radtke U (1989) Marine Terrassen und Korallenriffe. Das Problem der quartären Meeresspiegelschwankungen erläutert an Fallstudien aus Chile, Argentinien und Barbados. Düsseldorfer Geographische Schriften, Heft 27 , Düsseldorf

Riascos JM (2009) Thriving and declining: population dynamics of the macha (Mesodesma donacium, Bivalvia, Mesodesmatidae) along a latitudinal gradient of the Humboldt Current Upwelling System. PhD dissertation, University of Bremen 
Riascos JM, Heilmayer O, Oliva ME, Laudien J, Arntz WE (2008) Infestation of the surf clam Mesodesma donacium by the spionid polychaete Polydora bioccipitalis. J Sea Res 59:217-227

Rozbaczylo N, Schiede P, Sánchez M (1980) Polydora sp. (Polychaeta, Spionidae) a parasite of the clam Mesodesma donacium (Mollusca, Mesodesmatidae). Arch Biol Med Exp 13:105

Ruellet T (2004) Infestation des coquilles d'huîtres Crassostrea gigas par les polydores en Basse-Normandie: recommandations et mise au point d'un traitement pour réduire cette nuisance. $\mathrm{PhD}$ dissertation, Université de Caen, Basse-Normandie

Sato-Okoshi W, Okoshi K (1997) Survey of the genera Polydora, Boccardiella and Boccardia (Polychaeta, Spion-

Editorial responsibility: Sven Klimpel,

Düsseldorf, Germany idae) in Barkley Sound (Vancouver Island, Canada), with special reference to boring activity. Bull Mar Sci 60:428-493

Sato-Okoshi W, Takatsuka M (2001) Polydora and related genera (Polychaeta: Spionidae) around Puerto Montt and Chiloé Island (Chile), with description of a new species of Dipolydora. Bull Mar Sci 68:485-503

Simon CA, Ludford A, Wynne S (2006) Spionid polychaetes infestating cultured abalone Haliotis midae in South Africa. Afr J Mar Sci 28:167-171

Thiel M, Macaya EC, Arntz WE, Bastias H and others (2007) The Humboldt Current System of northern and central Chile. Oceanogr Mar Biol Annu Rev 45:195-345

Zar JH (1999) Biostatistical analysis, 4th edn. Prentice-Hall, Upper Saddle River, NJ

Submitted: December 11, 2008; Accepted: April 20, 2009

Proofs received from author(s): June 7, 2009 